\title{
Strobilanthes ovata (Acanthaceae), a New Species from Gaoligong Shan in Yunnan, China
}

\author{
Deng Yunfei \\ Key Laboratory of Plant Resources, Conservation, and Sustainable Utilization, South China \\ Botanical Garden, Chinese Academy of Sciences, Guangzhou, 510650, People's \\ Republic of China. yfdeng@scib.ac.cn
}

John R. I. Wood

Department of Plant Sciences, University of Oxford, South Parks Road, Oxford, OX1 3RB, United Kingdom. jriwood@hotmail.com

\section{Li Heng}

Key Laboratory of Biodiversity and Biogeography, Kunming Institute of Botany, Chinese Academy of Sciences, Kunming 650204, People's Republic of China. liheng@mail.kib.ac.cn

Abstract. A new species, Strobilanthes ovata Y. F. Deng \& J. R. I. Wood (Acanthaceae), is described and illustrated. The new species is another endemic species from Gaoligong Shan in southwest Yunnan similar to $S$. decipiens J. R. I. Wood, but differs in its glabrous leaves, winged rachis, the distant, spicate flowers, and the ovate, oblong-ovate, or rounded bracts.

Key words: Acanthaceae, China, IUCN Red List, Strobilanthes.

Gaoligong Shan is a 600-km-long, high-elevation mountain range that straddles the border between Yunnan Province in China and Kachin State in Burma (Myanmar) over much of its length. This range is situated at the heart of a vast biodiversity hotspot under severe threat of destruction through human activity (Li et al., 2000; Myers et al., 2000; Stotz et al., 2003; Chaplin, 2005; Liu \& Kress, 2005). In the past 10 years, a biodiversity survey in the Gaoligong Shan was conducted jointly by the Kunming Institute of Botany, Chinese Academy of Sciences (KUN), and the California Academy of Sciences (CAS) to study the flora of this area. More than 30,000 collections were made and several new species were found $(\mathrm{Yi} \& \mathrm{Li}$, 2001; Li \& Li, 2002; Wang, 2008; Li \& Hu, 2009). Among them, two new species of Strobilanthes Blume, S. lihengiae Y. F. Deng \& J. R. I. Wood and S. euantha J. R. I. Wood, have been described by us (Wood et al., 2003a; Deng et al., 2006). In the course of identifying specimens of Acanthaceae from Gaoligong Shan, we found another new species of Strobilanthes characterized by its winged inflorescence rachis and ovate inflorescence bracts. The new species is described and illustrated below.

doi: $10.3417 / 2009114$
Strobilanthes ovata Y. F. Deng \& J. R. I. Wood, sp. nov. TYPE: China. Yunnan: Baoshan Shi, Longyang Qu, Lihuipo, summit of Gaoligong Shan, 2100 m, 17 Nov. 2000, Li Heng with Dao Zhilin \& Yin Liwei 13101 (holotype, KUN; isotype, CAS). Figure 1.

Species nova Strobilanthis decipientis J. R. I. Wood affinis, sed ab ea foliis glabris, floribus distantibus in rhachim alatam dispositis, bracteis ovatis oblongo-ovatis vel orbiculatis et bracteolis oblanceolatis differt.

Perennial herb, 30-40 cm tall; stems with a narrow wing up to $0.75 \mathrm{~mm}$ wide on each side, glabrous, densely covered with cystoliths. Leaves petiolate near the base, becoming sessile apically; petioles of lower leaves 3-5 mm, glabrous; blades of lower leaves $2-5 \times$ 1-2 cm, ovate-elliptic, glabrous, apex acuminate, margin crenate to crenate-serrate, base decurrent; blades of upper leaves $2-3 \times 1.2-2.3 \mathrm{~cm}$, cordate, glabrous, apex acuminate, base cordate, margin crenate to crenate-serrate; all leaf blades with cystoliths prominent on both surfaces, paler abaxially with prominent veins covered by cystoliths, lateral veins in 2 to 4 pairs. Inflorescence of spikes terminal on main stem or on branches arising from the uppermost leaf axils, 1-7 cm; rachis narrowly winged, pilose with multicellular hairs, some gland-tipped; bracts ovate, oblong-ovate, or rounded, 3-7 × 1-5 mm, pubescent; bracteoles oblanceolate, ca. $5 \times 1 \mathrm{~mm}$, apex rounded, subglabrous to pilose with multicellular hairs, some gland-tipped; calyx subglabrous when immature, becoming glandular-pilose on the margin, weakly 2lipped, the upper lip 8-10 mm, 3-lobed, lobes triangular, 5-7 mm, connate for ca. $3 \mathrm{~mm}$ above base, 


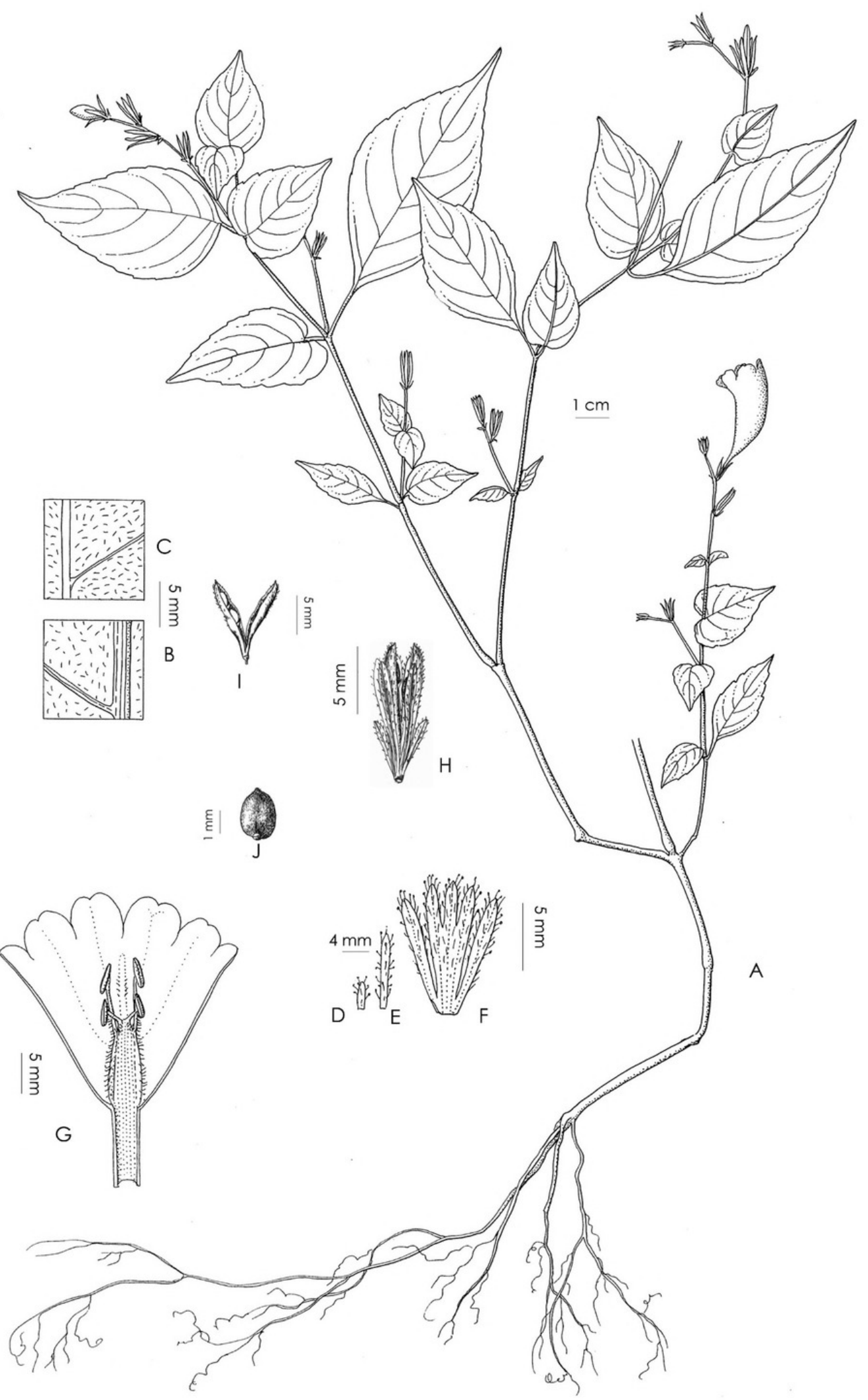

Figure 1. Strobilanthes ovata Y. F. Deng \& J. R. I. Wood. - A. Habit. —B. Leaf blade, abaxial surface. —C. Leaf blade, adaxial surface. -D. Bract. - E. Bracteole. -F. Calyx. - G. Corolla opened to show stamens. - H. Fruiting calyx. - I. Capsule. - J. Seed. A-G drawn by Rosemary Wise from the type Li Heng, Dao Zhilin \& Yin Liwei 13101 (CAS); H-J drawn by Liu Yunxiao from the paratype Xin Haijing 39 (IBSC). 


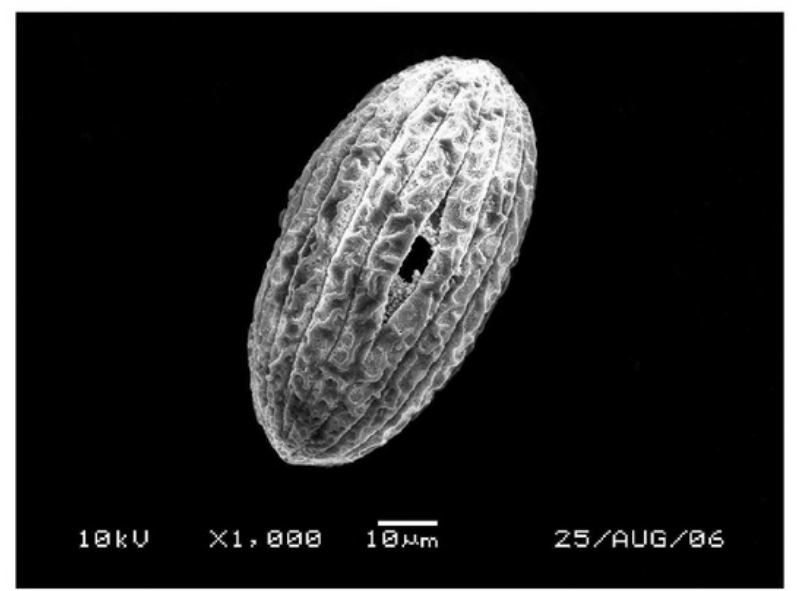

Figure 2. SEM image of pollen of Strobilanthes ovata Y. F. Deng \& J. R. I. Wood. Pollen sampled from Zhou Xuan $553(\mathrm{KUN})$.

lower lip 2-lobed almost to the base, the lobes 9-10 $\mathrm{mm}$, linear-oblanceolate to subspatulate, obtuse; corolla light blue, 3-3.5 cm, gently curved, subventricose, outside glabrous, inside glabrous except for trichomes retaining the style, base cylindrical, ca. $10 \times 2 \mathrm{~mm}$, then gradually widened to ca. $1.3 \mathrm{~cm}$ at mouth, subequally 5 -lobed, lobes ovate, ca. $4 \times 4 \mathrm{~mm}$; stamens 4 , didynamous, included; filaments of the longer pair ca. $5 \mathrm{~mm}$ long, pilose below, the shorter pair ca. $2 \mathrm{~mm}$ long, glabrous; anthers oblong, ca. $2 \times 1 \mathrm{~mm}$; pollen ellipsoid, tricolporate, $76.8 \times 40 \mu \mathrm{m}$, polar axis $(\mathrm{P})$ :equatorial diameter $(\mathrm{E})=1.92$, ribbed, bireticulate, pseudocolpi 12, scalariform (Fig. 2); ovary oblong, ca. $2 \mathrm{~mm}$, comose at tip; style ca. $2.2 \mathrm{~cm}$, sparsely pilose. Capsules narrowly oblong-ellipsoid, ca. $12 \times$ $2 \mathrm{~mm}$, glabrous except for glandular pubescence at tip, 4-seeded; seeds ovate or suborbicular, ca. $3 \times 2 \mathrm{~mm}$, pilose with mucilaginous hairs.

Distribution and habitat. Strobilanthes ovata was found in southeast and northwest Yunnan, China, growing in moist forest at altitudes from 1800 to $2100 \mathrm{~m}$.

IUCN Red List category. There have been no comprehensive field surveys of populations of Strobilanthes ovata, so this species should be classified as Data Deficient (DD) according to IUCN Red List criteria (IUCN, 2001). Further field research may provide a more precise conservation assessment in the future.

Phenology. The new species was observed in flower from October to February, with fruiting from December to March.

Etymology. The species epithet was derived from the Latin "ovatus," meaning "ovate," and refers to the ovate inflorescence bracts.
Relationships. Strobilanthes ovata is similar to $S$. decipiens J. R. I. Wood, but differs in its glabrous leaves (vs. densely pilose), winged rhachis (vs. wingless), distant flowers (vs. imbricate), and ovate, oblong-ovate, or rounded bracts (vs. obovate) (Wood \& Scotland, 2003b). It also bears some resemblance to $S$. rubescens T. Anderson in its glabrous leaves that are whitish abaxially and in the sessile upper leaves, but it can be easily distinguished by the glandular-pilose indumentum of the calyx.

Paratypes. CHINA. Yunnan: Baoshan Shi, Longyang Qu, Lihuipo, 16 Nov. 2000, Li Heng with Dao Zhilin \& Yin Liwei 13171 (CAS, KUN); Baoshan Shi, Longyang Qu, Lihuipo, 23 Jan. 2008, Deng Yunfei 20458 (IBSC); Baoshan Shi, Longyang Qu, Lihuipo, 29 Sep. 2008, Xin Haijing 39 (IBSC); Honghe Xian, Shui Yumin 94008A (KUN); Jinping Xian, s.d., Dept. of Biology, Yunnan University s.n. (KUN); Luchun Xian, way to Laobian, 2200 m, 19 Oct. 1971, Tao Deding 1095 (KUN); Tengchong Xian, 1959, Zhou Xuan 553 (KUN).

Acknowledgments. We are grateful to the curators of the following herbaria for their help: CAS, IBSC, KUN, and PE. The first author thanks Shi Xiaochun from Gaoligong Shan National Natural Reserve for his help in the fieldwork. Thanks are also due to Rosemary Wise (FHO) and Liu Yunxiao (IBSC) for preparing the line drawing, and Gao Chunming (IBSC) for observing the pollen. The work was supported by the National Natural Science Foundation of China (grant no. 30370109, 30670142, 30870152, 39899400, 30499340), the Knowledge Innovation Program of the Chinese Academy of Sciences (grant no. KSCX-SW122), the National Science Foundation (grant no. DEB0103795), and the Director Foundation of South China Botanical Garden, Chinese Academy of Sciences (grant no. 2002-1112).

\section{Literature Cited}

Chaplin, G. 2005. Physical geography of the Gaoligong Shan area of Southwest China in relation to biodiversity. Proc. Calif. Acad. Sci., ser. 4 56: 527-556.

Deng, Y. F., J. R. I. Wood \& R. W. Scotland. 2006. New and reassessed species of Strobilanthes (Acanthaceae) in the flora of China. Bot. J. Linn. Soc. 150: 369-390.

IUCN. 2001. IUCN Red List Categories and Criteria, Version 3.1. Prepared by the IUCN Species Survival Commission. IUCN, Gland, Switzerland, and Cambridge, United Kingdom.

Li, H., H. J. Guo \& Z. L. Dao. 2000. Flora of Gaoligong Mountain. Science Press, Beijing.

Li, R. \& C. M. Hu. 2009. Primula lihengiana (Primulaceae), a new species from Yunnan, China. Ann. Bot. Fenn. 46: 130-132.

— \& H. Li. 2002. Two new taxa of Maianthemum (Convallariaceae) from northwestern Yunnan, China. Novon 12: 486-491.

Liu, A. Z. \& W. J. Kress. 2005. The Gaoligong Mountains of southwest China and northeast Myanmar. Pp. 86-92 in G. A. Krupnick \& W. J. Kress (editors), Plant Conser- 
vation: A Natural History Approach. University of Chicago Press, Chicago.

Myers, N., R. A. Mittermeier, C. G. Mittermeier, G. A. B. da Fonseca \& J. Kent. 2000. Biodiversity hotspots for conservation priorities. Nature 403: 853-858.

Stotz, D. F., E. J. Harris, D. K. Moskovits, K. Hao, S. Yi \& G. W. Adelmann (editors). 2003. China: Yunnan, Southern Gaoligongshan. Rapid Biological Inventories Report No. 4. The Field Museum, Chicago.
Wang, W. T. 2008. New taxa of Ranunculaceae from Yunnan. Acta Bot. Yunnan. 30: 519-528.

Wood, J. R. I. \& R. W. Scotland. 2003a. Strobilanthes: Panicled species from East Asia. Kew Bull. 58: 679-702. $\&$ - 2003b. The 2-lipped species of Strobilanthes (Acanthaceae). Kew Bull. 58: 83-129.

Yi, T. S. \& H. Li. 2001. Arisaema danzhuense (Araceae), a new species from the Gaoligong Mountains, northwestern Yunnan, China. Novon 11: 512-514. 


\section{$2 \mathrm{BHL}$ Biodiversity Heritage Library}

Deng, Yunfei, Wood, J. R. I., and Li, Heng. 2010. "Strobilanthes ovata (Acanthaceae), a New Species from Gaoligong Shan in Yunnan, China." Novon a journal of botanical nomenclature from the Missouri Botanical Garden 20, 143-146.

View This Item Online: https://www.biodiversitylibrary.org/item/123332

Permalink: https://www.biodiversitylibrary.org/partpdf/121996

\section{Holding Institution}

Missouri Botanical Garden, Peter H. Raven Library

\section{Sponsored by}

Missouri Botanical Garden

\section{Copyright \& Reuse}

Copyright Status: Permission to digitize granted by rights holder Rights: https://www.biodiversitylibrary.org/permissions

This document was created from content at the Biodiversity Heritage Library, the world's largest open access digital library for biodiversity literature and archives. Visit BHL at https://www.biodiversitylibrary.org. 